\title{
Diversity of Crops and Land Use Pattern in Barisal Region
}

\author{
M Ibrahim ${ }^{1 *}$, M A U Zaman², A B M Mostafizur² and S M Shahidullah²
}

\begin{abstract}
Development workers, researchers and extensionists always need a comprehensive understanding and a reliable database on existing cropping patterns, cropping intensity and crop diversity of a particular area for the planning of future research and development. With this view, a survey-work was implemented over all the upazilas of Barisal region during 2016. A pre-tested semi-structured questionnaire was used as tool to document the existing cropping patterns, cropping intensity and crop diversity of the area. In the current investigation, 103 cropping patterns were identified. The highest number of cropping patterns 40 was found in Burhanuddin upazila of Bhola district and the lowest eight was in Betagi and Taltali of Barguna. The most dominant cropping pattern single T. Aman occupied $13.40 \%$ of net cropped area (NCA) of the region with its distribution over 33 upazilas out of 42 . The second largest area, $10.44 \%$ of NCA, was covered by Boro-Fallow- T. Aman, which was spread out over 32 upazilas. The lowest crop diversity index (CDI) was recorded 0.221 in Agailjhara of Barisal district followed by 0.598 in Bhandaria of Pirojpur. The highest value of CDI was observed 0.972 in Charfasson followed by 0.968 in Tazumuddin of Bhola. The range of cropping intensity values was observed $107-249 \%$. The maximum value was for Bhola sadar and minimum for Agailjhara of Barisal. The overall CDI of Barisal region was calculated 0.968 and the grand mean for cropping intensity at regional level was $204 \%$.
\end{abstract}

Key words: Land use, cropping intensity, cropping pattern, crop diversity and tidal wetland

\section{INTRODUCTION}

In Bangladesh a huge number of crops are produced under different cropping patterns with a variability from one region to another. Yearly sequences of crop production in a piece of land in a year is known as cropping pattern (Alam, 1994). Factors such as rainfall, climate, agricultural technology, soil type, insect and disease pressure, availability of irrigation facilities and other inputs, marketing and transport facilities, subsistence pressure and the growth of agro-industries etc changes the cropping pattern (Neena, 1998; Gadge, 2003; Rashid et al., 2005).

Cultivable land area is decreasing day by day in the country. In this context, there is no other alternative but to address less favourable and unfavourable environments. In the past
Barisal region was known as granary of the state. This region mainly represents tidal wetland ecosystem of both saline and nonsaline type. The crop production is restricted due to salinity in some areas during dry season. In the other areas it is affected by daily tide and monsoon tide. River bank erosion, exposure to cyclones and storm surges, risk of heavy late rainfall, torrential rain drip and remoteness of southern parts of the regions from urban markets are the limitation of this area (FAO, 1988). To increase the system productivity of the total environment it needs to bring diversity in enterprises for better utilization of limited resources. Diversified cropping pattern may be the strategic option for the farmers to coping strategy against the risks (Mandal and Bezbaruah, 2013). Typology of different cropping systems is the base for the managers

${ }^{1}$ BRRI RS Satkhira; ${ }^{2}$ Rice Farming Systems Division, BRRI, Gazipur; ${ }^{*}$ Corresponding author's E-mail: ibrahim1270@ yahoo.com 
of these systems to intensify production (Shriar, 2000). There is a strong need for judicious and appropriate use of limited resources in case of intervention selection that does not lead to increased mal adaption or inequity in the society over long term. An increased understanding of arable land use based on the cropping system is essential for the appropriate intervention in sustainable way. In this context, existing cropping patterns along with their diversity of such complex agricultural region are very crucial for risk minimization and overall productivity improvement. On the basis of afore-said discussion, the present study was undertaken with the following specific objectives to:

- Understand the existing cropping patterns scenario in Barisal region

- Visualize the existing land use pattern at upazila and regional level

- Determine the crop diversity and cropping intensity at local and regional level.

- Generate bench mark information of crop diversity and land use pattern in Barisal region.

\section{METHODOLOGY}

Forty-two upazilas of Barisal, Bhola, Barguna, Patuakhali, Pirojpur and Jhalakati district under Barisal agricultural region were the locale of this study. Data were collected using double stage procedure. At initial stage, data were collected through pretested semi structured questionnaire from 42 preassigned Sub-Assistant Agriculture Officers (SAAO) of each upazila during September 2016 at upazila level. SAAOs were purposively preselected by Agriculture Extension Officers (AEO), Additional Agriculture Officer (AAO) and Upazila Agriculture Officer (UAO) or altogether. Prior to data collection, the pretested questionnaire was explained along with proper guidelines to the AEOs or UAOs or both and handed over to them at each Deputy Director's office of Department of Agricultural
Extension (DAE) during monthly meeting for the sake of accurate data collection. The filled questionnaires were collected by the scientists of RFS Division, checked and analyzed to find the inconsistencies of the supplied data before validation workshop. All the inconsistencies among the information were documented. The collected data along with documented inconsistencies were discussed in district level workshop for necessary correction and validation. Second stage of data collection was day-long data validation workshop at district level during 20 to 24 November 2016. Four field-workers i.e. One SAPPO and three SAAOs experienced and engaged in cropbased data documentation, all officers from all upazilas viz UAOs, AEOs, AAEOs, DD (DAE), DD (Horticulture), DD of Seed Certification Agency, DTO and ADDs, one representative from Agricultural Training Institute (ATI) and scientists of BRRI Regional Station, Barisal, participated in the data validation workshop. The number participants of validation workshop ranged from 42 to 94 in each district. All the participants were divided into three to four groups for data validation. Each group was facilitated by two RFSD scientists to finalize and validate the data and authenticated data were captured. Crop diversity index was calculated by using the following equation described by Kshirsagar et al. (1997).

$$
C D I_{i}=1-\sum_{j=o}^{n}\left(\frac{a_{i j}}{A_{i}}\right)^{2}
$$

Where, $\mathrm{CDI}_{\mathrm{i}}=$ Crop Diversity Index

$a_{i j}=$ Area planted to the $j^{\text {th }}$ crop in the $i^{\text {th }}$ location

$\mathrm{A}_{\mathrm{i}}=$ Total area planted under all crops

The index is zero for a land area growing only one crop. It approaches unity as the level of diversity increases. Compilation and processing of collected data were done using Micro Soft Excel programme. Descriptive statistics were used to facilitate the presentation of the findings. 


\section{RESULTS AND DISCUSSION}

\section{Land use}

Table 1 presents the status of agricultural land utilization. The net cropped area of the Barisal region is 790,470 ha. Crops occupied the particular land for round the year were considered under annual crops. The major annual crops reported in the region were banana, papaya, betel leaf, ginger and turmeric. The annual crops area in different upazilas ranged from 20 to 4,310 ha. The annual crops area accounted only $2.18 \%$ of the net cropped area (NCA) in the region. At a glance the region possesses $18.27 \%$ single cropped area (SCA), 54.86\% double cropped area (DCA), $23.92 \%$ triple cropped area (TCA). The SCA had the major share of NCA in Agailjhara of Barisal, Taltali and sadar upazila of Barguna, Kalapara of Patuakhali and Nazirpur and Mathbaria upazilas of Pirojpur district followed by corresponding DCA. Most of the upazilas were dominated by DCA with exceptions in Bhola sadar and Barguna sadar upazila where triple cropped area is dominating (Table 1). The area which could not be defined under SCA, DCA, TCA or QCA was considered as others whose coverage is less than $1 \%$ of the NCA. This region mainly represents tidal wetland ecosystem of both saline and nonsaline type. The crop production is restricted due to salinity in some area during dry season. In the other area it is affected by daily tide and monsoon tide. River bank erosion, exposure to cyclones and storm surges, risk of heavy late rainfall, torrential rain drip and remoteness of southern parts of the regions from urban markets are the limitation of this area (FAO, 1988). Because of these limiting factors land-use intensity is somewhat lower than that of other regions of the country with favourable environments. Increased use of surface water irrigation might improve the situation to some extent.

\section{Cropping patterns of Barisal}

In total 103 cropping patterns were recorded in Barisal region of which 10 cropping patterns with exclusive rice crop covers approximately $36 \%$ of the NCA. There were 14 cropping patterns with exclusive non-rice crop covering only around $2 \%$ of the NCA. Rest of the NCA i.e. about $62 \%$ area is covered by 79 rice - non rice cropping patterns (Appendix 1).

\section{Sole rice and non-rice cropping patterns at a glance}

Table 2 lists 10 cropping patterns where rice was the only crop round the year. It comprises about $36 \%$ of the NCA in the region. Among them single rice, double rice and triple rice areas represented around $18 \%, 17 \%$ and $1 \%$, respectively. It reflects the unparallel dominance of rice in the cropping systems in Barisal region. In case of individual pattern single T. Aman has the highest coverage $(13.40 \%)$ and was recorded in 33 upazilas out of 42. The second dominant pattern Boro-FallowT. Aman area occupied $10.21 \%$ of NCA, which was reported in 32 upazilas. Fallow-Aus- T. Aman and the single Boro covered $5.44 \%$ and $4.44 \%$ area with its existence in only 26 and 14 upazilas respectively.

In the current investigation, 14 cropping patterns were identified where only non-rice crops are grown. Among these 14 patterns first nine have been arranged in descending order in Table 3. The rest five patterns with negligible area coverage (Table 7) were arranged with other patterns of different categories. Aggregate of the 14 patterns have had only $2.24 \%$ of NCA. In critical comparison it is clear that exclusive rice area is about 16 folds of exclusive non-rice area. Among these 14 patterns, three patterns comprise year-round vegetables distributed over majority of the upazilas. Year-round vegetable production system has occupied about nine-tenths of the non-rice cropping area and mainly practised on or alongside the homestead area.

\section{Pulse crops under cropping systems}

Twenty-seven cropping patterns with different pulse crops were found across the region (Table 4). Among them grasspea is covering the largest area whereas blackgram is cultivated in the smallest area. Four main cropping patterns of grasspea jointly cover approximately $17 \%$ of NCA. Mungbean holds the second position in pulse crop cultivation in Barisal region. There are two main cropping patterns for 
Table 1. Land use of different upazilas in Barisal region (area in hectare), 2014-15.

\begin{tabular}{|c|c|c|c|c|c|c|c|c|c|c|}
\hline & Upazila & $\begin{array}{l}\text { Area of } \\
\text { upazila }\end{array}$ & $\begin{array}{l}\text { Annual } \\
\text { crop }\end{array}$ & SCA & DCA & TCA & QCA & Other & NCA & C.I. $(\%)$ \\
\hline 01 & Agailjhara & 15552 & 180 & 10100 & 450 & 145 & 0 & 155 & 11030 & 107 \\
\hline 02 & Babuganj & 15247 & 210 & 600 & 8620 & 2410 & 0 & 170 & 12010 & 214 \\
\hline 03 & Bakerganj & 40050 & 700 & 6150 & 11420 & 11100 & 0 & 130 & 29500 & 214 \\
\hline 04 & Banaripara & 13486 & 445 & 2950 & 2950 & 1110 & 0 & 145 & 7600 & 169 \\
\hline 05 & Barisal sadar & 26172 & 175 & 4020 & 14000 & 915 & 0 & 170 & 19280 & 183 \\
\hline 06 & Gournadi & 14938 & 1175 & 200 & 7000 & 2475 & 0 & 130 & 10980 & 210 \\
\hline 07 & Hizla & 33859 & 230 & 750 & 11300 & 1040 & 0 & 160 & 13480 & 200 \\
\hline 08 & Mehendiganj & 41896 & 500 & 0 & 18640 & 3700 & 0 & 160 & 23000 & 214 \\
\hline 09 & Muladi & 23050 & 800 & 1050 & 10025 & 2970 & 0 & 155 & 15000 & 208 \\
\hline 10 & Wazirpur & 24932 & 680 & 7500 & 7950 & 310 & 0 & 140 & 16580 & 152 \\
\hline 11 & Bhola sadar & 41316 & 230 & 1300 & 9870 & 14050 & 0 & 180 & 25630 & 249 \\
\hline 12 & Burhanuddin & 28400 & 230 & 70 & 13120 & 6880 & 0 & 130 & 20430 & 232 \\
\hline 13 & Charfasson & 144004 & 4310 & 5500 & 41100 & 26180 & 0 & 210 & 77300 & 221 \\
\hline 14 & Daulatkhan & 29310 & 110 & 1200 & 6990 & 5990 & 0 & 120 & 14410 & 233 \\
\hline 15 & Lalmohan & 39600 & 130 & 0 & 16915 & 8300 & 0 & 135 & 25480 & 232 \\
\hline 16 & Monpura & 35300 & 95 & 1040 & 9250 & 1715 & 0 & 130 & 12230 & 205 \\
\hline 17 & Tazumuddin & 51931 & 100 & 20 & 7755 & 2880 & 0 & 145 & 10900 & 226 \\
\hline 18 & Amtali & 47758 & 60 & 1500 & 12620 & 9130 & 0 & 150 & 23460 & 232 \\
\hline 19 & Bamna & 9227 & 85 & 1300 & 2660 & 2870 & 0 & 115 & 7030 & 221 \\
\hline 20 & Betagi & 16800 & 190 & 600 & 5700 & 5750 & 0 & 150 & 12390 & 241 \\
\hline 21 & Barguna & 38853 & 175 & 6100 & 3370 & 15220 & 0 & 105 & 24970 & 236 \\
\hline 22 & Patharghata & 38730 & 60 & 1500 & 12650 & 3200 & 0 & 150 & 17560 & 209 \\
\hline 23 & Taltali & 24242 & 60 & 8260 & 4180 & 1600 & 0 & 160 & 14260 & 152 \\
\hline 24 & Jhalakati & 21293 & 1250 & 2600 & 8650 & 2400 & 0 & 170 & 15070 & 190 \\
\hline 25 & Kathalia & 15747 & 800 & 1400 & 5580 & 2825 & 0 & 145 & 10750 & 206 \\
\hline 26 & Nalchity & 21077 & 600 & 2040 & 10600 & 1040 & 0 & 120 & 14400 & 189 \\
\hline 27 & Rajapur & 16433 & 180 & 4600 & 5120 & 1605 & 0 & 175 & 11680 & 172 \\
\hline 28 & Bauphal & 48185 & 190 & 1550 & 29400 & 5670 & 0 & 180 & 36990 & 211 \\
\hline 29 & Dashmina & 30074 & 220 & 500 & 16030 & 1820 & 0 & 150 & 18720 & 206 \\
\hline 30 & Dumki & 9513 & 45 & 600 & 5050 & 1190 & 0 & 145 & 7030 & 208 \\
\hline 31 & Galachipa & 52614 & 390 & 1000 & 24500 & 7625 & 0 & 175 & 33690 & 219 \\
\hline 32 & Kalapara & 49210 & 20 & 21300 & 17725 & 1200 & 0 & 175 & 40420 & 150 \\
\hline 33 & Mirzaganj & 17552 & 120 & 2400 & 1640 & 7310 & 0 & 100 & 11570 & 242 \\
\hline 34 & Patuakhali & 36014 & 260 & 2400 & 20280 & 4970 & 0 & 150 & 28060 & 208 \\
\hline 35 & Rangabali & 48000 & 100 & 6200 & 14625 & 14250 & 0 & 125 & 35300 & 223 \\
\hline 36 & Bhandaria & 16356 & 540 & 5000 & 3430 & 720 & 0 & 150 & 9840 & 150 \\
\hline 37 & Kawkhali & 7867 & 150 & 2100 & 2260 & 410 & 0 & 130 & 5050 & 163 \\
\hline 38 & Mathbaria & 35325 & 240 & 9600 & 9210 & 1690 & 0 & 100 & 20840 & 161 \\
\hline 39 & Nazirpur & 24849 & 300 & 8355 & 7735 & 310 & 0 & 100 & 16800 & 150 \\
\hline 40 & Nesarabad & 18343 & 220 & 4050 & 5990 & 615 & 0 & 145 & 11020 & 166 \\
\hline 41 & Pirojpur & 16387 & 550 & 3600 & 5020 & 2910 & 0 & 120 & 12200 & 190 \\
\hline \multirow[t]{2}{*}{42} & Zianagar & 9255 & 130 & 3400 & 2280 & 600 & 0 & 120 & 6530 & 154 \\
\hline & Barisal region & & 17235 & 144405 & 433660 & 189100 & 0 & 6070 & 790470 & 204 \\
\hline
\end{tabular}

60 Ibrahim et al 
Table 2. Cropping patterns with exclusive rice in Barisal region, 2014-15.

\begin{tabular}{llrrr}
\hline & Cropping pattern & Area (ha) & \% of NCA & Frequency (no. of upazila) \\
\hline 01 & Fallow-Fallow- T. Aman & 105950 & 13.40 & 33 \\
02 & Boro-Fallow- T. Aman & 80710 & 10.21 & 32 \\
03 & Fallow-Aus- T. Aman & 43000 & 5.44 & 26 \\
04 & Boro-Fallow-Fallow & 35100 & 4.44 & 14 \\
05 & Boro-Aus- T. Aman & 10230 & 1.29 & 6 \\
06 & Fallow-B.Aus+B.Aman & 2570 & 0.33 & 3 \\
07 & Fallow-B.Aman & 1950 & 0.25 & 5 \\
08 & Boro-B.Aman & 1870 & 0.24 & 2 \\
09 & Boro-Aus-Fallow & 1190 & 0.15 & 1 \\
10 & Fallow-Aus-Fallow & 330 & 0.04 & 3 \\
\hline & Total & 282900 & 35.79 & \\
\hline
\end{tabular}

Table 3. Cropping patterns with exclusive non-rice in Barisal region, 2014-15.

\begin{tabular}{|c|c|c|c|c|}
\hline & Cropping pattern & Area (ha) & $\%$ of NCA & Frequency (no. of upazila) \\
\hline 01 & Vegetab-Vegetab-Vegetab & 8555 & 1.08 & 21 \\
\hline 02 & Vegetab-Vegetab-Fallow & 7450 & 0.94 & 16 \\
\hline 03 & Grasspea-Jute-Fallow & 400 & 0.05 & 1 \\
\hline 04 & Coriander-Vegetab-Fallow & 350 & 0.04 & 3 \\
\hline 05 & Coriander-Fallow-Fallow & 280 & 0.35 & 6 \\
\hline 06 & Chilli-Vegetab-Fallow & 230 & 0.03 & 2 \\
\hline 07 & Vegetab-Jute-Fallow & 170 & 0.02 & 2 \\
\hline 08 & S.Potato-Fallow-Fallow & 60 & 0.01 & 1 \\
\hline 09 & Vegetab-Fallow-Fallow & 60 & 0.01 & 2 \\
\hline \multirow[t]{2}{*}{$10-14$} & Other five patterns (in Table 7) & 160 & 0.02 & - \\
\hline & Total & 17715 & 2.24 & \\
\hline
\end{tabular}

Table 4. Area for pulse crops under different cropping systems in Barisal region, 2014-15.

\begin{tabular}{|c|c|c|c|c|}
\hline & Cropping pattern & Area (ha) & $\%$ of NCA & Frequency (no. of upazila) \\
\hline 01 & Mungbean-Fallow- T. Aman & 83770 & 10.60 & 35 \\
\hline 02 & Grasspea-Fallow- T. Aman & 66030 & 8.35 & 33 \\
\hline 03 & Grasspea-Aus- T. Aman & 63140 & 7.99 & 39 \\
\hline 04 & Mungbean-Aus- T. Aman & 45640 & 5.77 & 28 \\
\hline 05 & Felon-Fallow- T. Aman & 16275 & 2.06 & 15 \\
\hline 06 & Felon-Aus- T. Aman & 4200 & 0.53 & 5 \\
\hline 07 & Lentil-Fallow- T. Aman & 3950 & 0.50 & 25 \\
\hline 08 & Chickpea-Fallow-T. Aman & 2445 & 0.31 & 19 \\
\hline 09 & Grasspea-Jute- T. Aman & 2250 & 0.28 & 5 \\
\hline 10 & Lentil-Jute- T. Aman & 1260 & 0.16 & 6 \\
\hline 11 & Lentil-Aus- T. Aman & 1090 & 0.14 & 12 \\
\hline 12 & Grasspea-Jute-Fallow & 400 & 0.05 & 1 \\
\hline 13 & Chickpea-Aus-T. Aman & 340 & 0.04 & 4 \\
\hline 14 & Blackgram-Jute- T. Aman & 220 & 0.03 & 1 \\
\hline \multirow[t]{2}{*}{$15-27$} & Other 13 patterns (in Table 7) & 735 & 0.09 & - \\
\hline & Total pulse crops & 291745 & 36.90 & \\
\hline
\end{tabular}


mungbean viz Mungbean-Fallow-T. Aman and Mungbean-Aus- T. Aman. These two patterns in-together occupy over $16 \%$ of NCA. In the documentation of pulse cropping systems adoption of grasspea was dominant across the region hence proved its widest adaptability. One pattern is available in 39 upazilas and the other exists in 33 upazilas. Finally the aggregate area of the pulse cropping system stands for about $37 \%$ of the NCA in Barisal region. In the tidal wetland ecosystem surface water for irrigation is not sufficient or limited access. Groundwater from shallow tubewell is mostly saline in nature. Deep tubewell is not available in the area. For all the said factors Boro can not be cultivated normally. Moreover, most of the T. Aman cultivars are local type and of photoperiod sensitive in nature which cause the late harvest of the crop. In that case most of the Rabi crops can not suit for plantation. Among the rabi crops stress-tolerant grasspea can easily be grown as relay system. The mungbean is a short duration mild drought and salt-tolerant crop with photo-insensitive in nature. With all these advantages grasspea and mungbean are extensively cultivated in the area (FAO, 1988).
Oil-seed crops under cropping systems

Groundnut is the most important one among the oil-seed crops in Barisal region. There are 21 cropping patterns for oil-seed crops among which only two patterns had been led by groundnut, however it is spread over 26 upazilas in the region (Table 5). The total share of oil-seed cropping patterns is about $6 \%$ of NCA whereas groundnut alone occupies $2.55 \%$. Mustard covers over $1 \%$. However, the highest number of the oil-seed cropping patterns are led by mustard and it is distributed in 23 out of 42 upazilas in the region.

\section{Vegetables and spices crops}

There are 39 cropping patterns arranged in descending order according to area coverage (Table 6). Potato and other vegetables of Rabi, Kharif-I and Kharif-II; spices viz chilli, onion, garlic, coriander are included in this list. The most dominant cropping pattern is ChilliFallow- T. Aman covering 3.50\% of NCA which is distributed over 36 upazilas. The second one is Vegetables-Fallow- T. Aman covering 1.98\% of NCA and it is recorded in 32 upazilas out of 42. The aggregated area allotted for vegetables and spices crops was 94,285 hectares that is equivalent to $11.93 \%$ of NCA in the region. The main spices crop is chilli which was grown in

Table 5. Area foroil-seedcrops under different cropping systems in Barisal region, 2014-15.

\begin{tabular}{llcc}
\hline Cropping pattern & Area (ha) & \% of NCA & Frequency (no. of upazila) \\
\hline 01 Groundnut-Fallow- T. Aman & 14665 & 1.86 & 26 \\
02 Sesame-Fallow- T. Aman & 6560 & 0.83 & 14 \\
03 Groundnut- Aus- T. Aman & 5485 & 0.69 & 8 \\
04 Soybean-Fallow- T. Aman & 4600 & 0.58 & 3 \\
05 Mustard-Boro- T. Aman & 2640 & 0.33 & 4 \\
06 Mustard-Aus- T. Aman & 2510 & 0.32 & 10 \\
07 Mustard-Fallow- T. Aman & 2155 & 0.27 & 23 \\
08 Sunflower-Fallow- T. Aman & 1610 & 0.20 & 12 \\
09 Soybean-B.Aman & 800 & 0.10 & 2 \\
10 Sesame-Aus- T. Aman & 720 & 0.09 & 4 \\
11 Mustard-Jute- T. Aman & 610 & 0.08 & 4 \\
12 Mustard-Sesame- T. Aman & 560 & 0.07 & 2 \\
13 Soybean-Jute- T. Aman & 530 & 0.07 & 3 \\
14 Fallow-Sesame- T. Aman & 490 & 0.06 & 4 \\
15 Soybean-Aus- T. Aman & 470 & 0.06 & 2 \\
16 Potato-Sesame- T. Aman & 380 & 0.05 & 5 \\
$17-21$ Other five patterns (in Table 7) & 405 & 0.05 & - \\
\hline Total oil-seed crops & 45190 & 5.72 & \\
\hline
\end{tabular}

62 Ibrahim et al 
Table 6. Vegetables and spices crops under different cropping patterns in Barisal region, 2014-15.

\begin{tabular}{|c|c|c|c|c|}
\hline & Cropping pattern & Area (ha) & $\%$ of NCA & Freq. (no. of upazila) \\
\hline 01 & Chilli-Fallow- T. Aman & 27700 & 3.50 & 36 \\
\hline 02 & Vegetab-Fallow- T. Aman & 15640 & 1.98 & 32 \\
\hline 03 & Vegetab-Vegetab- T. Aman & 9040 & 1.14 & 21 \\
\hline 04 & Vegetab-Vegetab-Vegetab & 8555 & 1.08 & 21 \\
\hline 05 & Vegetab-Vegetab-Fallow & 7450 & 0.94 & 16 \\
\hline 06 & Chilli-Aus- T. Aman & 7040 & 0.89 & 13 \\
\hline 07 & Potato-Fallow- T. Aman & 4620 & 0.58 & 25 \\
\hline 08 & Potato-Aus- T. Aman & 4400 & 0.56 & 10 \\
\hline 09 & Vegetab-Aus- T. Aman & 3810 & 0.48 & 13 \\
\hline 10 & Potato-Vegetab- T. Aman & 750 & 0.09 & 7 \\
\hline 11 & Coriander-Fallow- T. Aman & 615 & 0.08 & 15 \\
\hline 12 & Potato-Boro- T. Aman & 520 & 0.07 & 3 \\
\hline 13 & Onion-Aus- T. Aman & 455 & 0.06 & 8 \\
\hline 14 & Garlic-Aus- T. Aman & 445 & 0.06 & 8 \\
\hline 15 & Garlic-Fallow- T. Aman & 430 & 0.05 & 13 \\
\hline 16 & Potato-Sesame- T. Aman & 380 & 0.05 & 5 \\
\hline 17 & Coriander-Vegetab-Fallow & 350 & 0.04 & 3 \\
\hline 18 & Coriander-Fallow-Fallow & 280 & 0.04 & 6 \\
\hline 19 & Onion-Fallow- T. Aman & 270 & 0.03 & 14 \\
\hline 20 & Fallow-Vegetab- T. Aman & 260 & 0.03 & 2 \\
\hline 21 & Chilli-Vegetab-Fallow & 230 & 0.03 & 2 \\
\hline $22-39$ & Other 18 patterns (in Table 7) & 1045 & 0.13 & - \\
\hline Total fo & r vegetables and spices crops & 94285 & 11.93 & \\
\hline
\end{tabular}

an area of 35,000 ha (4.43\% of NCA). Probably two congenial factors encourages the famers for growing chilli viz favourable environments of charland and easy availability of women labour for harvesting and post harvest management of the crop (FAO, 1988).

\section{Sporadic and distinct cropping patterns}

There were some cropping patterns which were extremely location-specific, however, with a large area coverage. These are SoybeanFallow- T. Aman (Table 5); Fallow-B. Aus+B. Aman and Boro-Aus-Fallow (Table 2). Area coverage of Soybean-Fallow- T. Aman was 4,600 hectares that distributed in Hizla $(2,700$ ha), Mehendiganj (500 ha) of Barisal district and in Tazumuddin (1,400 ha) in Bhola district. Fallow-B. Aus+B. Aman is limited to three upazilas viz Nesarabad (2,300 ha), Nazirpur (250 ha) and Kawkhali (20 ha) of Pirojpur district. Boro-Aus-Fallow is available in Nazirpur (1,100 ha) of Pirojpur and Agailjhara (90 ha) of Barisal district.

\section{Rare cropping patterns}

In the present investigation, 34 cropping patterns have been identified as rare with a negligible area coverage with seldom existence (Table 7). These are location specific system and are limited in one to four upazilas of the region. Total area coverage of these 34 patterns is only $0.28 \%$ of NCA. Among these the highest area was occupied by Mustard-MungbeanT. Aman (185 ha) and it is recorded in three upazilas viz Babuganj of Barisal, Burhanuddin of Bhola and Dashmina upazila of Patuakhali district. The smallest area was recorded for Lentil-Mungbean-T. Aman whose coverage was five hectares only (Table 7).

\section{Most dominant cropping pattern}

Single T. Aman was the most dominant cropping pattern in Barisal region. It covers $13.70 \%$ of NCA in the region and is available in 33 upazilas out of 42 (Table 8). The highest area under this cropping was recorded 21,300 hectares in Kalapara upazila of Patuakhali 
Table 7. Rare cropping patterns covering non-significant area in Barisal region, 2014-15.

\begin{tabular}{|c|c|c|c|c|c|}
\hline & Cropping pattern & Area (ha) & $\%$ of NCA & Frequency & Upazila \\
\hline 01 & Mustard-Mung T. Aman & 185 & 0.02 & 3 & Babuganj+Borhan.+Dashmina \\
\hline 02 & Vegetab-Jute-Fallow & 170 & 0.02 & 2 & Banaripara+Ujirpur \\
\hline 03 & Boro-Jute-Fallow & 160 & 0.02 & 1 & Agailjhara \\
\hline 04 & Grasspea-B.Aus+B.Aman & 150 & 0.02 & 1 & Nesarabad \\
\hline 05 & Maize-Aus- T. Aman & 130 & 0.02 & 4 & Bhola+Boran+Kalapara+Zianagar \\
\hline 06 & Potato-Jute- T. Aman & 110 & 0.01 & 1 & Babuganj \\
\hline 07 & Boro-Vegetab(Float/Norm) & 100 & 0.01 & 1 & Ujirpur \\
\hline 08 & Lentil-Sesame- T. Aman & 100 & 0.01 & 1 & Jhalkathi \\
\hline 09 & Onion-Jute- T. Aman & 85 & 0.01 & 2 & Muladi \\
\hline 10 & Coriander-Sesame- T. Aman & 80 & 0.01 & 1 & Bhola \\
\hline 11 & Millet(kaon)-F- T. Aman & 80 & 0.01 & 2 & Hijla \\
\hline 12 & Coriander-Jute- T. Aman & 70 & 0.01 & 2 & Gournadi+Muladi \\
\hline 13 & S.Potato-Fallow-Fallow & 60 & 0.01 & 1 & Taltoli \\
\hline 14 & S.Potato-Jute- T. Aman & 60 & 0.01 & 2 & Babuganj+Gournadi \\
\hline 15 & Vegetab-Fallow-Fallow & 60 & 0.01 & 2 & Monpura+Tajumuddin \\
\hline 16 & Blackgram-Aus- T. Aman & 55 & 0.01 & 3 & Gournadi+Muladi+Kalapara \\
\hline 17 & Garlic-Jute- T. Aman & 50 & 0.01 & 1 & Muladi \\
\hline 18 & Garlic-Vegetab-Vegetab & 50 & 0.01 & 3 & Borhan + Najirpur+Nesarabad \\
\hline 19 & Grasspea-Mung- T. Aman & 50 & 0.01 & 1 & Dumki \\
\hline 20 & Lentil-Vegetab- T. Aman & 50 & 0.01 & 1 & Jhalkathi \\
\hline 21 & Onion-Vegtab-Vegetab & 50 & 0.01 & 3 & Borhan+Najirpur+Nesarabad \\
\hline 22 & Lentil-Vegetab-Vegetab & 40 & 0.01 & 1 & Bhola \\
\hline 23 & Grasspea-Sesame- T. Aman & 30 & 0.00 & 1 & Gournadi \\
\hline 24 & Potato-Maize- T. Aman & 30 & 0.00 & 1 & Najirpur \\
\hline 25 & Potato-Mungbean- T. Aman & 30 & 0.00 & 1 & Najirpur \\
\hline 26 & Potato-S.gourd-Aus & 30 & 0.00 & 1 & Borhanuddin \\
\hline 27 & Chilli-Vegetab-T. Aman & 20 & 0.00 & 1 & Borhanuddin \\
\hline 28 & Mungbean-B.Aus+B.Aman & 20 & 0.00 & 1 & Nesarabad \\
\hline 29 & Chilli-Jute- T. Aman & 10 & 0.00 & 1 & Gournadi \\
\hline 30 & Mungbean-Jute- T. Aman & 10 & 0.00 & 1 & Gournadi \\
\hline 31 & Mustard-Fallow-Fallow & 10 & 0.00 & 1 & Nesarabad \\
\hline 32 & Pea-Fallow- T. Aman & 10 & 0.00 & 2 & Muladi+Kathatoli \\
\hline 33 & Potato-Jute-Fallow & 10 & 0.00 & 1 & Gournadi \\
\hline \multirow[t]{2}{*}{34} & Lentil-Mungbean- T. Aman & 5 & 0.00 & 1 & Dumki \\
\hline & Total & 2160 & 0.28 & & \\
\hline
\end{tabular}

district. This area is $53.12 \%$ of the NCA in that Kalapara upazila. In another consideration it occupies $20.10 \%$ of total Fallow-Fallow-T. Aman area of the region. Taltali upazila of Barguna district has allocated its highest area for the single T. Aman pattern and it is $57.50 \%$ of its NCA. However, in respect of total region, this upazila had hold the $3^{\text {rd }}$ position in the area coverage for this pattern. Soil salinity is a constraint for the cultivation of Boro rice and Rabi crops in Kalapara, Mathbaria, Taltali and other saline-prone area. A large area of this pattern is distributed on the charland where irrigation water is not sufficiently available in winter season. All these are the limiting factors for the crop intensification (FAO, 1988). Some stress-tolerant Rabi crops like grasspea, felon, cowpea, sesame etc may undergo for trial to intensify the land-use of the aforesaid system. In the country-wide compilation of data it was observed that the single T. Aman was the third dominant cropping pattern in Bangladesh 
Table 8. Distribution of the most dominant Fallow-Fallow- T. Aman cropping pattern in Barisal region, $2014-15$.

\begin{tabular}{|c|c|c|c|c|}
\hline & Upazila & Area (ha) & $\%$ of upazila NCA & $\%$ of the pattern in region \\
\hline 01 & Kalapara & 21300 & 53.12 & 20.10 \\
\hline 02 & Mathbaria & 9200 & 44.35 & 8.68 \\
\hline 03 & Taltali & 8200 & 57.50 & 7.74 \\
\hline 04 & Rangabali & 6200 & 18.18 & 5.85 \\
\hline 05 & Barguna & 6100 & 24.42 & 5.76 \\
\hline 06 & Bakerganj & 6000 & 20.34 & 5.66 \\
\hline 07 & Charfasson & 5000 & 6.58 & 4.72 \\
\hline 08 & Bhandaria & 5000 & 50.81 & 4.72 \\
\hline 09 & Rajapur & 4600 & 39.36 & 4.34 \\
\hline 10 & Zianagar & 3400 & 52.00 & 3.21 \\
\hline 11 & Barisal sadar & 3300 & 17.09 & 3.11 \\
\hline 12 & Pirojpur & 3000 & 24.54 & 2.83 \\
\hline 13 & Mirzaganj & 2400 & 20.73 & 2.27 \\
\hline 14 & Patuakhali sadar & 2400 & 20.73 & 2.27 \\
\hline 15 & Kawkhali & 2100 & 41.53 & 1.98 \\
\hline 16 & Nesarabad & 1800 & 17.03 & 1.70 \\
\hline 17 & Jhalakati & 1700 & 11.28 & 1.60 \\
\hline 18 & Amtali & 1500 & 6.39 & 1.42 \\
\hline 19 & Patharghata & 1500 & 8.54 & 1.42 \\
\hline 20 & Kathalia & 1400 & 13.02 & 1.32 \\
\hline 21 & Bamna & 1300 & 18.48 & 1.23 \\
\hline 22 & Daulatkhan & 1200 & 8.95 & 1.13 \\
\hline 23 & Bauphal & 1200 & 3.24 & 1.13 \\
\hline 24 & Monpura & 1000 & 8.16 & 0.94 \\
\hline 25 & Galachpipa & 1000 & 3.04 & 0.94 \\
\hline 26 & Muladi & 700 & 4.66 & 0.66 \\
\hline 27 & Hizla & 630 & 4.75 & 0.59 \\
\hline 28 & Betagi & 600 & 4.84 & 0.57 \\
\hline 29 & Dumki & 600 & 8.49 & 0.57 \\
\hline 30 & Banaripara & 500 & 6.61 & 0.47 \\
\hline 31 & Nalchity & 500 & 3.49 & 0.47 \\
\hline 32 & Dashmina & 500 & 2.67 & 0.47 \\
\hline \multirow[t]{2}{*}{33} & Nazirpur & 120 & 0.76 & 0.11 \\
\hline & Barisal region & 105950 & 13.70 & 100.00 \\
\hline
\end{tabular}

covering 5.09 lac ha ( $6 \%$ of NCA in the country) with its distribution in 162 upazilas of 32 districts (Nasim et al., 2017).

\section{Second dominant cropping pattern}

The second dominant cropping pattern in Barisal region is Mungbean-Fallow- T. Aman. It belongs to $10.60 \%$ of NCA of the region and spread in 35 upazilas (Table 9). Bauphal upazila of Patuakhali district holds the highest area $(15,000 \mathrm{ha})$ under this cropping followed by Dashmina upazila $(10,300 \mathrm{ha})$ of the same district. These two upazilas jointly contribute
$30.21 \%$ share of Mungbean-Fallow- T. Aman cropping area in the region. Monpura upazila of Bhola district stands in the fifth position, however, this upazila has allocated maximum share $(60 \%)$ of its NCA.

\section{Third dominant cropping pattern}

Boro-Fallow- T. Aman cropping pattern holds the third largest area coverage 80,710 ha in Barisal region. This area is an equivalent to $10.21 \%$ of NCA in the region. However, this pattern is widely distributed over 32 upazilas of Barisal region. Among these upazilas 
Table 9. Distribution of the $2^{\text {nd }}$ dominant cropping pattern Mungbean-Fallow- T. Aman in Barisal region, $2014-15$.

\begin{tabular}{|c|c|c|c|c|}
\hline & Upazila & Area (ha) & $\%$ of upazila NCA & $\%$ of the pattern in region \\
\hline 01 & Bauphal & 15000 & 40.76 & 17.91 \\
\hline 02 & Dashmina & 10300 & 55.68 & 12.30 \\
\hline 03 & Patuakhali sadar & 10000 & 35.97 & 11.94 \\
\hline 04 & Patharghata & 8500 & 48.57 & 10.15 \\
\hline 05 & Monpura & 7300 & 60.08 & 8.71 \\
\hline 06 & Charfasson & 6000 & 8.23 & 7.16 \\
\hline 07 & Galachipa & 5100 & 15.32 & 6.09 \\
\hline 08 & Babuganj & 3600 & 30.51 & 4.30 \\
\hline 09 & Amtali & 2820 & 12.05 & 3.37 \\
\hline 10 & Barisal sadar & 2450 & 12.83 & 2.92 \\
\hline 11 & Rangabali & 2000 & 5.68 & 2.39 \\
\hline 12 & Dumki & 1700 & 24.29 & 2.03 \\
\hline 13 & Tazumuddin & 1100 & 10.19 & 1.31 \\
\hline 14 & Muladi & 850 & 5.99 & 1.01 \\
\hline 15 & Bakerganj & 800 & 2.78 & 0.95 \\
\hline 16 & Mehendiganj & 700 & 3.11 & 0.84 \\
\hline 17 & Bhola sadar & 600 & 2.36 & 0.72 \\
\hline 18 & Kalapara & 600 & 1.49 & 0.72 \\
\hline 19 & Dualatkhan & 500 & 3.50 & 0.60 \\
\hline 20 & Lalmohan & 500 & 1.97 & 0.60 \\
\hline 21 & Taltali & 500 & 3.52 & 0.60 \\
\hline 22 & Hizla & 480 & 3.62 & 0.57 \\
\hline 23 & Wazirpur & 400 & 2.52 & 0.48 \\
\hline 24 & Barguna sadar & 400 & 1.61 & 0.48 \\
\hline 25 & Kathalia & 300 & 3.02 & 0.36 \\
\hline 26 & Gournadi & 220 & 2.24 & 0.26 \\
\hline 27 & Jhalakati & 200 & 1.45 & 0.24 \\
\hline 28 & Nalchity & 200 & 1.45 & 0.24 \\
\hline 29 & Mirzaganj & 200 & 1.75 & 0.24 \\
\hline 30 & Rajapur & 180 & 1.57 & 0.21 \\
\hline 31 & Nazirpur & 120 & 0.73 & 0.14 \\
\hline 32 & Burhanuddin & 50 & 0.25 & 0.06 \\
\hline 33 & Bhandaria & 50 & 0.54 & 0.06 \\
\hline 34 & Kawkhali & 30 & 0.61 & 0.04 \\
\hline \multirow[t]{2}{*}{35} & Zianagar & 20 & 0.31 & 0.02 \\
\hline & Barisal region & 83770 & 10.60 & 100.00 \\
\hline
\end{tabular}

Lalmohan of Bhola has the biggest area of 9,200 ha for the pattern, which stands for $11.40 \%$ of the total area under this pattern in the region (Table 10). Gournadi upazila of Barisal district ranks in sixth position for Boro-Fallow-T. Aman, however, this upazila has allotted the biggest share $(53.06 \%)$ of its NCA. Here it is clear that Barisal region is quite different than national level. In the country-wide compilation of data it was observed that Boro-F-T. Aman was the most dominant cropping pattern in
Bangladesh covering 2.31 million ha $(27 \%$ of NCA in the country) with its distribution in 426 upazilas of 63 districts (Nasim et al., 2017).

\section{Fourth dominant cropping pattern}

Fourth dominant cropping pattern GrasspeaFallow- T. Aman has occupied 65,960 hectares representing $8.34 \%$ share of NCA in Barisal region (Table 11). This pattern is widely distributed over 32 upazilas where Mathbaria of Pirojpur district ranked in top position. This

66 Ibrahim et al 
Table 10. Distribution of the $3^{\text {rd }}$ dominant cropping pattern Boro-F- T. Aman in Barisal region, 2014-15.

\begin{tabular}{|c|c|c|c|c|}
\hline & Upazila & Area (ha) & $\%$ of upazila NCA & $\%$ of the pattern in region \\
\hline 01 & Lalmohan & 9200 & 36.29 & 11.40 \\
\hline 02 & Charfasson & 9000 & 12.35 & 11.15 \\
\hline 03 & Burhanuddin & 8450 & 41.83 & 10.47 \\
\hline 04 & Mehendiganj & 6000 & 26.67 & 7.43 \\
\hline 05 & Wazirpur & 5800 & 36.48 & 7.19 \\
\hline 06 & Gournadi & 5200 & 53.06 & 6.44 \\
\hline 07 & Daulatkhan & 4500 & 31.47 & 5.58 \\
\hline 08 & Bhola sadar & 3600 & 14.17 & 4.46 \\
\hline 09 & Barisal sadar & 3500 & 18.32 & 4.34 \\
\hline 10 & Jhalakati & 3000 & 21.74 & 3.72 \\
\hline 11 & Nazirpur & 2800 & 16.97 & 3.47 \\
\hline 12 & Hizla & 2600 & 19.62 & 3.22 \\
\hline 13 & Banaripara & 2550 & 35.66 & 3.16 \\
\hline 14 & Muladi & 2400 & 16.90 & 2.97 \\
\hline 15 & Nalchity & 2200 & 15.94 & 2.73 \\
\hline 16 & Pirojpur sadar & 2000 & 17.17 & 2.48 \\
\hline 17 & Bakerganj & 1800 & 6.25 & 2.23 \\
\hline 18 & Babuganj & 1200 & 10.17 & 1.49 \\
\hline 19 & Tazumuddin & 900 & 8.33 & 1.12 \\
\hline 20 & Mathbaria & 900 & 4.37 & 1.12 \\
\hline 21 & Nesarabad & 800 & 7.41 & 0.99 \\
\hline 22 & Bauphal & 500 & 1.36 & 0.62 \\
\hline 23 & Galachipa & 400 & 1.20 & 0.50 \\
\hline 24 & Barguna & 350 & 1.41 & 0.43 \\
\hline 25 & Dashmina & 350 & 1.89 & 0.43 \\
\hline 26 & Kathalia & 200 & 2.01 & 0.25 \\
\hline 27 & Kalapara & 200 & 0.50 & 0.25 \\
\hline 28 & Rangabali & 200 & 0.57 & 0.25 \\
\hline 29 & Rajapur & 50 & 0.43 & 0.06 \\
\hline 30 & Dumki & 20 & 0.29 & 0.02 \\
\hline 31 & Bhandaria & 20 & 0.22 & 0.02 \\
\hline \multirow[t]{2}{*}{32} & Zianagar & 20 & 0.31 & 0.02 \\
\hline & Barisal region & 80710 & 10.21 & 100.00 \\
\hline
\end{tabular}

upazila has 6,200 ha area for Grasspea-FallowT. Aman which is $29.89 \%$ of its NCA and it is the highest share among all the upazilas.

\section{Fifth dominant cropping pattern}

The fifth dominant cropping pattern GrasspeaAus- T. Aman had been covering 63,140 hectares representing $7.99 \%$ share of NCA in Barisal region (Table 12). This pattern also is widely distributed over 32 upazilas where Barguna sadar ranked in top position. This upazila had 10,200 ha area for Grasspea-AusT. Aman pattern which represented $41.13 \%$ of upazila NCA. Mirzaganj upazila had the $3^{\text {rd }}$ largest area 5,000 ha for this cropping, however, this upazila had the biggest share $(43.67 \%)$ of its NCA.

\section{Crop diversity and cropping intensity}

Higher number of available crops under cultivation in an area dictates its higher diversity. Number of cropping patterns is also a gross indicator of crop diversity. A total of 103 cropping patterns were identified in the whole area of Barisal region under this investigation. The highest number of cropping patterns was identified 40 in Burhanuddin upazila of Bhola district followed by 37 in Bhola sadar upazila; 
and 32 in Hizla and Mehendiganj of Barisal district (Table 13). In contrast, the lowest number of cropping patterns was identified 8 in Betagi and Taltoli followed by 10 in Patharghata of Barguna district. The higher number of cropping patterns is generally related to higher level of crop diversity indices. The upazilas having lower number of cropping patterns were related to either salinity or water logging or both. The lowest diversity index for cropping pattern was recorded 0.152 in Agailjhara of Barisal followed by 0.598 in Taltali of Barguna. In a study Shahidullah et al. (2006) also found lowest values for all the diversity and intensity parameters in salt affected area of greater Noakhali. The highest value of diversity index for cropping patterns was found 0.937 in Charfason upazila that was followed by 0.926 in Tazumuddin upazila of Bhola. The lowest CDI was reported 0.221 in Agailjhara followed by 0.598 in Bhandaria. The highest value of CDI was observed 0.972 in Charfason followed by 0.968 in Tazumuddin upazila. Diversified cropping pattern may enabled the farmers compulsion of extracting the maximum possible use of land in the flood free period (Mandal and Bezbaruah, 2013). Singh and Sidhu (2006) reported that a number of crops like sun hemp, cluster beans

Table 11. Distribution of the $4^{\text {th }}$ dominant Grasspea-Fallow- T. Aman cropping pattern in Barisal region, $2014-15$.

\begin{tabular}{|c|c|c|c|c|}
\hline & Upazila & Area (ha) & $\%$ of upazila NCA & $\%$ of the pattern in region \\
\hline 01 & Mathbaria & 6200 & 29.89 & 9.39 \\
\hline 02 & Patuakhali sadar & 5200 & 18.55 & 7.88 \\
\hline 03 & Kalapara & 5100 & 12.72 & 7.72 \\
\hline 04 & Bauphal & 4500 & 12.15 & 6.82 \\
\hline 05 & Mehendiganj & 4200 & 18.22 & 6.36 \\
\hline 06 & Barisal sadar & 4000 & 20.71 & 6.06 \\
\hline 07 & Muladi & 3600 & 23.98 & 5.45 \\
\hline 08 & Taltali & 3400 & 23.84 & 5.15 \\
\hline 09 & Patharghata & 3100 & 17.65 & 4.69 \\
\hline 10 & Lalmohan & 2900 & 11.38 & 4.39 \\
\hline 11 & Betagi & 2800 & 22.60 & 4.24 \\
\hline 12 & Babuganj & 2500 & 20.80 & 3.79 \\
\hline 13 & Hizla & 2300 & 17.35 & 3.48 \\
\hline 14 & Amtali & 2300 & 9.80 & 3.48 \\
\hline 15 & Galachpipa & 2000 & 6.09 & 3.03 \\
\hline 16 & Dumki & 1700 & 24.06 & 2.57 \\
\hline 17 & Bhandaria & 1600 & 16.26 & 2.42 \\
\hline 18 & Tazumuddin & 1500 & 13.66 & 2.27 \\
\hline 19 & Rajapur & 1200 & 10.27 & 1.82 \\
\hline 20 & Katahalia & 900 & 8.37 & 1.36 \\
\hline 21 & Nalchity & 750 & 5.24 & 1.14 \\
\hline 22 & Nazirpur & 700 & 4.46 & 1.06 \\
\hline 23 & Jhalakati & 650 & 4.31 & 0.98 \\
\hline 24 & Dashmina & 600 & 3.20 & 0.91 \\
\hline 25 & Daulatkhan & 400 & 2.98 & 0.61 \\
\hline 26 & Bamna & 400 & 5.69 & 0.61 \\
\hline 27 & Wazirpur & 300 & 1.81 & 0.45 \\
\hline 28 & Monpura & 300 & 2.45 & 0.45 \\
\hline 29 & Gournadi & 260 & 2.68 & 0.39 \\
\hline 30 & Zianagar & 250 & 3.82 & 0.38 \\
\hline 31 & Kawkhali & 200 & 3.95 & 0.30 \\
\hline \multirow[t]{2}{*}{32} & Burhanuddin & 150 & 0.86 & 0.23 \\
\hline & Barisal region & 65960 & 8.34 & 100.00 \\
\hline
\end{tabular}

68 Ibrahim et al 
Table 12. Distribution of the $5^{\text {th }}$ dominant Grasspea-Aus- T. Aman cropping pattern in Barisal region, $2014-15$.

\begin{tabular}{|c|c|c|c|c|}
\hline & Upazila & Area (ha) & $\%$ of upazila NCA & $\%$ of the pattern in region \\
\hline 01 & Barguna & 10200 & 41.13 & 16.15 \\
\hline 02 & Bakerganj & 9000 & 31.25 & 14.25 \\
\hline 03 & Mirzaganj & 5000 & 43.67 & 7.92 \\
\hline 04 & Charfasson & 3700 & 5.08 & 5.86 \\
\hline 05 & Betagi & 3000 & 24.59 & 4.75 \\
\hline 06 & Rangabali & 3000 & 8.52 & 4.75 \\
\hline 07 & Amtali & 2600 & 11.11 & 4.12 \\
\hline 08 & Pirojpur & 2600 & 22.32 & 4.12 \\
\hline 09 & Bhola sadar & 2500 & 9.84 & 3.96 \\
\hline 10 & Kathalia & 2000 & 20.10 & 3.17 \\
\hline 11 & Bauphal & 1900 & 5.16 & 3.01 \\
\hline 12 & Muladi & 1750 & 12.32 & 2.77 \\
\hline 13 & Taltali & 1600 & 11.27 & 2.53 \\
\hline 14 & Lalmohan & 1500 & 5.92 & 2.38 \\
\hline 15 & Bamna & 1400 & 20.14 & 2.22 \\
\hline 16 & Patharghata & 1400 & 8.00 & 2.22 \\
\hline 17 & Daulatkhan & 1200 & 8.39 & 1.90 \\
\hline 18 & Mehendiganj & 1000 & 4.44 & 1.58 \\
\hline 19 & Galachipa & 1000 & 3.00 & 1.58 \\
\hline 20 & Patuakhali sadar & 1000 & 3.60 & 1.58 \\
\hline 21 & Nalchity & 700 & 5.07 & 1.11 \\
\hline 22 & Jhalakati & 650 & 4.71 & 1.03 \\
\hline 23 & Dashmina & 600 & 3.24 & 0.95 \\
\hline 24 & Burhanuddin & 550 & 2.72 & 0.87 \\
\hline 25 & Dumki & 500 & 7.14 & 0.79 \\
\hline 26 & Kawkhali & 400 & 8.16 & 0.63 \\
\hline 27 & Zianagar & 350 & 5.47 & 0.55 \\
\hline 28 & Hizla & 300 & 2.26 & 0.48 \\
\hline 29 & Bhandaria & 300 & 3.23 & 0.48 \\
\hline 30 & Mathbaria & 300 & 1.46 & 0.48 \\
\hline 31 & Gournadi & 200 & 2.04 & 0.32 \\
\hline 32 & Tazumuddin & 200 & 1.85 & 0.32 \\
\hline 33 & Rajapur & 200 & 1.74 & 0.32 \\
\hline 34 & Monpura & 150 & 1.23 & 0.24 \\
\hline 35 & Babuganj & 120 & 1.02 & 0.19 \\
\hline 36 & Wazirpur & 110 & 0.69 & 0.17 \\
\hline 37 & Kalapara & 100 & 0.25 & 0.16 \\
\hline 38 & Nazirpur & 30 & 0.18 & 0.05 \\
\hline \multirow[t]{2}{*}{39} & Nesarabad & 30 & 0.28 & 0.05 \\
\hline & Barisal region & 63140 & 7.99 & 100.00 \\
\hline
\end{tabular}


Table 13. Crop diversity and cropping intensity in Barisal region, 2014-15.

\begin{tabular}{|c|c|c|c|c|c|c|}
\hline & Upazila & $\begin{array}{c}\text { No. of identified } \\
\text { pattern }\end{array}$ & No. of crop & $\begin{array}{l}\text { Diversity index for } \\
\text { cropping pattern }\end{array}$ & $\begin{array}{l}\text { Crop diversity } \\
\text { index (CDI) }\end{array}$ & C.I. (\%) \\
\hline 01 & Agailjhara & 11 & 13 & 0.152 & 0.221 & 107 \\
\hline 02 & Babuganj & 21 & 19 & 0.842 & 0.928 & 214 \\
\hline 03 & Bakerganj & 19 & 15 & 0.836 & 0.916 & 214 \\
\hline 04 & Banaripara & 20 & 17 & 0.767 & 0.859 & 169 \\
\hline 05 & Barisal sadar & 22 & 14 & 0.865 & 0.927 & 183 \\
\hline 06 & Gournadi & 22 & 16 & 0.706 & 0.845 & 210 \\
\hline 07 & Hizla & 32 & 17 & 0.875 & 0.936 & 200 \\
\hline 08 & Mehendiganj & 32 & 19 & 0.877 & 0.944 & 214 \\
\hline 09 & Muladi & 28 & 16 & 0.889 & 0.943 & 208 \\
\hline 10 & Wazirpur & 18 & 14 & 0.669 & 0.799 & 152 \\
\hline 11 & Bhola sadar & 37 & 18 & 0.827 & 0.917 & 249 \\
\hline 12 & Burhanuddin & 40 & 22 & 0.706 & 0.870 & 232 \\
\hline 13 & Charfasson & 26 & 17 & 0.937 & 0.972 & 221 \\
\hline 14 & Daulatkhan & 25 & 15 & 0.847 & 0.936 & 233 \\
\hline 15 & Lalmohan & 24 & 17 & 0.833 & 0.934 & 232 \\
\hline 16 & Monpura & 16 & 16 & 0.625 & 0.816 & 205 \\
\hline 17 & Tazumuddin & 31 & 18 & 0.926 & 0.968 & 226 \\
\hline 18 & Amtali & 15 & 13 & 0.887 & 0.950 & 232 \\
\hline 19 & Bamna & 18 & 14 & 0.840 & 0.927 & 221 \\
\hline 20 & Betagi & 08 & 05 & 0.821 & 0.917 & 241 \\
\hline 21 & Barguna & 15 & 11 & 0.745 & 0.884 & 236 \\
\hline 22 & Patharghata & 10 & 09 & 0.712 & 0.865 & 209 \\
\hline 23 & Taltali & 08 & 08 & 0.598 & 0.786 & 152 \\
\hline 24 & Jhalakati & 26 & 18 & 0.909 & 0.953 & 190 \\
\hline 25 & Kathalia & 24 & 13 & 0.862 & 0.928 & 206 \\
\hline 26 & Nalchity & 23 & 17 & 0.833 & 0.906 & 189 \\
\hline 27 & Rajapur & 23 & 15 & 0.784 & 0.902 & 172 \\
\hline 28 & Bauphal & 27 & 16 & 0.801 & 0.907 & 211 \\
\hline 29 & Dashmina & 27 & 11 & 0.680 & 0.846 & 206 \\
\hline 30 & Dumki & 24 & 13 & 0.858 & 0.931 & 208 \\
\hline 31 & Galachipa & 28 & 17 & 0.918 & 0.965 & 219 \\
\hline 32 & Kalapara & 31 & 19 & 0.662 & 0.821 & 150 \\
\hline 33 & Mirzaganj & 20 & 16 & 0.736 & 0.878 & 242 \\
\hline 34 & Patuakhali & 21 & 15 & 0.812 & 0.912 & 208 \\
\hline 35 & Rangabali & 18 & 13 & 0.836 & 0.925 & 223 \\
\hline 36 & Bhandaria & 21 & 09 & 0.490 & 0.598 & 150 \\
\hline 37 & Kawkhali & 15 & 07 & 0.704 & 0.764 & 163 \\
\hline 38 & Mathbaria & 21 & 17 & 0.707 & 0.768 & 161 \\
\hline 39 & Nazirpur & 34 & 21 & 0.702 & 0.717 & 150 \\
\hline 40 & Nesarabad & 21 & 13 & 0.852 & 0.915 & 166 \\
\hline 41 & Pirojpur & 14 & 08 & 0.838 & 0.912 & 190 \\
\hline \multirow[t]{2}{*}{42} & Zianagar & 17 & 11 & 0.648 & 0.810 & 154 \\
\hline & Barisal region & 103 & 32 & 0.931 & 0.968 & 204 \\
\hline
\end{tabular}

and sorghum had almost disappeared and there is reduced varietal diversification in rice and wheat. Crop diversification index of wheat-rice system has decreased from 0.75 in 1975-76 to 0.58 in 2006-07 in Punjab though diversification forces pests to continuously relocate and re-colonize their preferred host plants from year to year (Tscharntke et al., 2005, 2007). The range of cropping intensity values was recorded $107-249 \%$. The maximum value was for Bhola sadar upazila of Barisal district and minimum for Agailjhrara upazila of Barisal

70 Ibrahim et al 
district. As a whole the CDI of Barisal region was calculated 0.968 and the average cropping intensity at regional level was 204\%. In a simultaneous study, the investigators identified 316 cropping patterns for whole Bangladesh; where the CDI value was 0.952 at national level and the national average of cropping intensity was 200\% (Nasim et al., 2017).

\section{CONCLUSION}

The cropping intensity of the Barisal region was very close to the national average. Single T. Aman, single Boro, MungbeanFallow-T. Aman, Boro-Fallow-T. Aman were the dominant cropping patterns in the region. Exclusive rice area is about 16 folds of exclusive non-rice area. The non-rice based cropping patterns were found few, however, its abundance is bigger than that of Sylhet, Chittagong and Khulna region over all. Based on the findings of the study, the following recommendations were made.

Initiative to be taken to increase productivity of exclusive rice based cropping pattern. High yielding salt tolerant rice varieties along with recommended crop management packages to be adopted. Several upazilas have unique or exceptional cropping patterns with large area coverage. Those might be studied in-depth to extrapolate to similar environments. Effort should be given so that a portion of single $\mathrm{T}$. Aman area could be shifted to Mungbean-T. Aman and/or Grasspea-T. Aman cropping systems. In the single Boro area suitable vegetables might be grown on floating bed system in wet season.

\section{REFERENCES}

Alam, M S. 1994. Optimum cropping patterns of the small farmers under risk: a micro level study in Bangladesh. PhD thesis, Department of Agricultural Economics, Bangladesh Agricultural University, Mymensingh.

FAO, 1988. Land Resources Appraisal of Bangladesh for Agricultural Development- Report 2: Agroecological regions of Bangladesh. Food and Agriculture Organization of the United Nations, Rome, Italy, 570p.

Gadge, S S. 2003. Influence of changes in cropping pattern on farmers' economic status. Indian J. Ext. Edu. 39(1\&2): 99-101.

Kshirsagar, K G, S Pandey and M R Bellon. 1997. Farmers' perception, varietal characteristics and technology adoption: the case of rainfed village in eastern India. Discussion paper 5/97. Social Sciences Division, International Rice Research Institute. Los Baňos, Laguna, Philippines.

Mandal, R and M P Bezbaruah. 2013. Diversification of cropping pattern: its determinants and role in flood affected agriculture of Assam Plains. Indian J. Agric. Econ. 68(2): 169-181.

Nasim, M, S M Shahidullah, A Saha, M A Muttaleb, T L Aditya, M A Ali and M S Kabir. 2017. Distribution of Crops and Cropping Patterns in Bangladesh. Bangladesh Rice J. 21(2): 1-55.

Rashid, M H, A H Khan and M M Alam. 2005. Cropping systems dynamics in greater Khustia. J. Bangladesh Agril. Univ. 3(2): 213-238.

Shahidullah, S M, M S A Talukder, M S Kabir, A H Khan and N E Elahi. 2006. Cropping patterns in the South East Coastal Region of Bangladesh. J. Agric. Rural Dev. 4(1\&2): 53-60.

Shriar, A J. 2000. Agricultural intensity and its measurement in frontier regions. Agroforestry Systems. 49(3): 301-318.

Singh, J. and R S Sidhu. 2006. Accounting for impact of environmental degradation in agriculture of Indian Punjab. Agric. Economics Res. Rev. 19: 37-48.

Tscharntke, T, R Bommarco, Y Clough, T O Crist, D Klein, $\mathrm{T}$ A Rand, J M Tylianakis, S vanNouhuys, and S Vidal. 2007. Conservation biological control and enemy diversity on a landscape scale. Biol. Control. 43: 294-309.

Tscharntke, T., A M Klein, A Kruess, I S Dewenter, and C Thies. 2005. Landscape perspectives on agricultural intensification and biodiversity-ecosystem service management. Ecol. Lett. 8: 857-874. 
Appendix 1. List of cropping patterns in Barisal region, 2014-15.

\begin{tabular}{|c|c|c|c|c|c|}
\hline & Cropping pattern & Area (ha) & & Cropping pattern & Area (ha) \\
\hline 01 & Fallow-Fallow- T. Aman & 105950 & 36 & Mustard-Fallow- T. Aman & 2155 \\
\hline 02 & Mungbean-Fallow- T. Aman & 83770 & 37 & Fallow-B.Aman & 1950 \\
\hline 03 & Boro-Fallow- T. Aman & 80710 & 38 & Muskmelon-F- T. Aman & 1935 \\
\hline 04 & Grasspea-Fallow- T. Aman & 66030 & 39 & Boro-B.Aman & 1870 \\
\hline 05 & Grasspea-Aus- T. Aman & 63140 & 40 & Sunflower-F- T. Aman & 1610 \\
\hline 06 & Mungbean-Aus- T. Aman & 45640 & 41 & Maize-Fallow- T. Aman & 1270 \\
\hline 07 & Fallow-Aus-T. Aman & 43000 & 42 & Lentil-Jute- T. Aman & 1260 \\
\hline 08 & Boro-Fallow-Fallow & 35100 & 43 & Boro-Aus-Fallow & 1190 \\
\hline 09 & Chilli-Fallow-T.Aman & 27700 & 44 & Lentil-Aus- T. Aman & 1090 \\
\hline 10 & W.Melon-Fallow- T. Aman & 22230 & 45 & Soybean-B.Aman & 800 \\
\hline 11 & Felon-Fallow- T. Aman & 16275 & 46 & Potato-Vegetab- T. Aman & 750 \\
\hline 12 & Vegetab-Fallow- T. Aman & 15640 & 47 & Sesame-Aus- T. Aman & 720 \\
\hline 13 & Groundnut-F- T. Aman & 14665 & 48 & Coriander-F- T. Aman & 615 \\
\hline 14 & S.Potato-Fallow- T. Aman & 10250 & 49 & Mustard-Jute- T. Aman & 610 \\
\hline 15 & Boro-Aus- T. Aman & 10230 & 50 & Mustard-Sesame- T.Aman & 560 \\
\hline 16 & W.Melon-Aus- T. Aman & 10100 & 51 & Soybean-Jute- T. Aman & 530 \\
\hline 17 & Vegetab-Vegetab- T. Aman & 9040 & 52 & Potato-Boro- T. Aman & 520 \\
\hline 18 & Vegetab-Vegetab-Vegetab & 8555 & 53 & Fallow-Sesame- T. Aman & 490 \\
\hline 19 & Vegetab-Vegetab-Fallow & 7450 & 54 & Soybean-Aus- T. Aman & 470 \\
\hline 20 & Chilli-Aus- T. Aman & 7040 & 55 & Onion-Aus- T. Aman & 455 \\
\hline 21 & Sesame-Fallow- T. Aman & 6560 & 56 & Garlic-Aus- T. Aman & 445 \\
\hline 22 & Groundnut- Aus- T. Aman & 5485 & 57 & Garlic-Fallow- T. Aman & 430 \\
\hline 23 & Wheat-Fallow- T. Aman & 4640 & 58 & Grasspea-Jute-Fallow & 400 \\
\hline 24 & Potato-Fallow- T. Aman & 4620 & 59 & Fallow-Jute- T. Aman & 390 \\
\hline 25 & Soybean-Fallow- T. Aman & 4600 & 60 & Potato-Sesame- T. Aman & 380 \\
\hline 26 & Potato-Aus- T. Aman & 4400 & 61 & Coriander-Vegetab-F & 350 \\
\hline 27 & Felon-Aus- T. Aman & 4200 & 62 & Chickpea-Aus-T. Aman & 340 \\
\hline 28 & Lentil-Fallow- T. Aman & 3950 & 63 & Fallow-Aus-Fallow & 330 \\
\hline 29 & Vegetab-Aus- T. Aman & 3810 & 64 & Coriander-Fallow-Fallow & 280 \\
\hline 30 & Mustard-Boro- T. Aman & 2640 & 65 & Onion-Fallow- T. Aman & 270 \\
\hline 31 & Fallow-B.Aus+B.Aman & 2570 & 66 & Fallow-Vegetab- T. Aman & 260 \\
\hline 32 & Mustard-Aus- T. Aman & 2510 & 67 & Chilli-Vegetab-Fallow & 230 \\
\hline 33 & Chickpea-Fallow-T. Aman & 2445 & 68 & Blackgram-Jute- T. Aman & 220 \\
\hline 34 & Wheat-Aus- T. Aman & 2410 & 69 & Wheat-Jute- T. Aman & 220 \\
\hline 35 & Grasspea-Jute- T. Aman & 2250 & $70-103$ & Other 34 patterns (Table 7) & 2160 \\
\hline
\end{tabular}

